M. A. BAilén, R. CHINCHILla, D. J. DODSWORTH, C. NÁJERA* (UNIVERSIDAD DE AliCANTE, SPAIN)

2-Mercaptopyridone 1-Oxide-Based Uronium Salts: New Peptide Coupling Reagents

J. Org. Chem. 1999, 64, 8936-8939, DOI: 10.1021/jo990660q.

\section{Thiopyridone-Derived Reagents for Peptide Coupling Reactions}

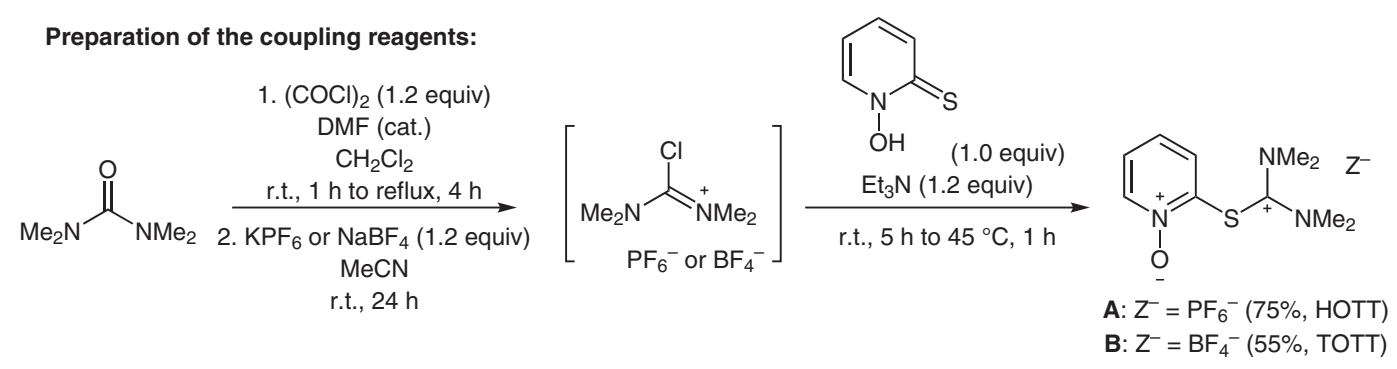

Selected examples for peptide coupling reactions:

\section{Category}

Peptide Chemistry

\section{Key words}

peptide bond formation

uronium salts

coupling agents

thiopyridones<smiles>COC(=O)CNC(=O)CNC(=O)OCc1ccccc1</smiles><smiles>COC(=O)[C@H](C)NC(=O)CNC(=O)OCc1ccccc1</smiles>

$89 \%$ yield $^{a}$ $87 \%$ yield $^{b}$<smiles>COC(=O)[C@H](NC(=O)C(C)(C)NC(=O)OCc1ccccc1)C(C)C</smiles>

$58 \%$ yield $^{a}$ $44 \%$ yield $^{\mathrm{b}}$<smiles>[Z17]C(C=O)C(=O)OC</smiles>

(1.0 equiv)

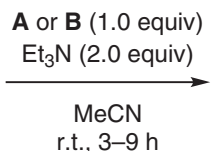<smiles></smiles>

$\bar{R}^{3}$
Significance: Peptide coupling reagents are extremely important in peptide synthesis. In 1999, Nájera and co-workers reported a method for synthesizing thiopyridone-derived uronium salts as coupling reagents. The reagents were prepared from cheap starting materials, making them more economical than conventional coupling reagents such as HOBt.
Comment: By using the thiopyridone-derived reagents as coupling reagents, various dipeptides were synthesized in moderate to excellent yields. 